\title{
Effect of Slurry Aeration on Coagulation: An Application of Irregular Factorial Design Analysis
}

\author{
Mustafa Çırak ${ }^{*}$ \\ Muğla Sitkı Koçman University, Engineering Faculty, Muğla
}

\begin{abstract}
The effect of the aeration on the coagulation of a bentonite suspension was tested in this study. The experimental runs for this coagulation work was formed with the help of the irregular factorial design. Based on this irregular fractional design, a statistical model $\left(\mathrm{R}^{2}=92.65 \%\right.$; $\mathrm{p}$-value $\left.<0.05\right)$ was computed to interpret the main effects and interactions of the independent parameters: $\mathrm{pH}$, aeration, and the $\mathrm{Al}$-coagulant. The suspension $\mathrm{pH}$ was determined as the most effective parameter in this system since the degree of the hydrolyses of aluminium directly varies as a function of $\mathrm{pH}$. Therefore, the increase in the suspension $\mathrm{pH}$ resulted in the higher sediment volumes whereas the minimum sediment volume was obtained at $\mathrm{pH}$ 5. Furthermore, the interaction effect of the product: $\mathrm{pHxaeration}$ in the statistical model was very critical for the performance of the process. Especially, at acidic pH levels, the aeration adversely affected the sediment formation after the coagulation. 3-D response surfaces of the estimated model also showed that the maximum amount of the Al-coagulant should be added at $\mathrm{pH} 5$ and no aeration should be applied for the minimization of the sediment volume.
\end{abstract}

Keywords: Coagulation, DOE, Aeration, clay, colloid, suspension.

\section{Süspansiyon İçerisindeki Hava Kabarcıklarının Koagülasyon Performansı Üzerindeki Etkisi: Faktöriyal Dizayn Analizi Uygulaması}

\begin{abstract}
$\ddot{O} z$
$\mathrm{Bu}$ çalışmada, bentonite süspansiyonunun koagülasyonu esnasında sisteme verilen hava kabarckklarının fizikokimyasal süreç üzerindeki etkileri incelenmiştir. Koagülasyon çalışması için gerekli deney seti, istatistiksel bir teknik olan fraksiyonel dizayn yöntemi ile oluşturulmuştur. Bu yöntem ile elde edilen istatistiksel model (R2 $=92.65 \%$; $\mathrm{p}$-value $<0.05)$ parametrelerin $(\mathrm{pH}$, havalandırma ve $\mathrm{Al}$-koagülant) sistem üzerindeki temel etkilerinin ve etklileşimlerinin belirlenmesinde ve yorumlanmasında kullanılmıştır. Sonuç olarak, alüminyum iyonlarının hidrolizinin temel olarak pH faktörü ile değişmesi sebebi ile süspansiyon pH'ının performans açısından en etkili bağımsız değişken olduğu görülmüştür. pH seviyesinin yükseltilmesi daha fazla çamur hacminin oluşmasına sebep olurken en düşük çökelen katı hacmi pH 5 değerinde elde edilmiştir. Ek olarak, istatistiksel eşitlikteki pHxhava etkileşiminin sistem performansı açısından kritik öneme sahip olduğu gözlemlenmiştir. Özellikle asidik pH seviyelerinde hava kabarcıkları koagülasyon performansını olumsuz etkilemiştir. İstatistiksel modele ait 3-Boyutlu etki yüzeyleri incelendiğinde ise koagülasyon sonrası elde edilen çamur hacminin minimize edilebilmesi için maksimum Al-koagülantı pH 5 seviyelerinde eklenmesi gerekliliği tespit edilmiştir. Süspansiyon içerisindeki hava kabarcıklarının ise flok oluşumunu engellediği ve optimum koagülasyon performansı için uygun bir parameter olmadığı sonucuna varılmıştır.
\end{abstract}

Anahtar Kelimeler: Koagülasyon, DOE, havalandırma, kil, kolloid, süspansiyon.

\section{Introduction}

The tailings of the mineral processing industries constitute of the large amount of solid and liquid mixtures, which has no or limited economic use. Generally, this kind of discharged tailings generates a

*Sorumlu yazar: mustafacirak@mu.edu.tr

Geliş Tarihi: 29.05.2018, Kabul Tarihi: 24.12.2018 
number of environmental problems such as the contamination of the groundwater and the surface water, the contamination of the soil and the disturbance of the landscape etc. In spite of the several efforts for the elimination and the rehabilitation of the tailings, the treatment of the slurry discharged from the mineral processing plants remains a technical difficulty in the wastewater management stage [1]. This technical difficulty commonly stems from the colloidal property of the solid matter in water and the high surface charges of the waste particles, for instance, the presence of the clay particles.

The coagulants are frequently used to destabilize these colloidal particles both in lab-scale and industrial applications. The most widely used coagulants are the aluminum and iron coagulants [2] since they are hydrolyzable metal species. Once these coagulants are hydrolyzed, they can be strongly adsorbed on the negatively charged mineral matters. As a result, the coagulants combine small particles into larger aggregates via the charge neutralization mechanism [3] and the compression of the electrical double layer $[4,5]$ when they are properly added into the waste stream of the mineral industries. The successful completion of the coagulation process is followed by the sedimentation and the filtration stages to achieve greater performance of the solid/liquid separation [6].

The effect of the aeration on Fe-coagulation was previously investigated by Chocksuchard et al. [7] and Konieczny et al. [8]. According to the results of these studies, Fe-coagulation has been proved as an efficient method for the elimination of the negatively charged colloidal particles. Nevertheless, the introduction of the air bubbles into the suspension reduced the size of the aggregates. Another study [9] was tested the effect of the aeration on the turbidity after coagulation process. The result of that study indicated that the aeration adversely affected the supernatant turbidity and the aggregate size upon the addition of the alum. The researchers [9] explained this drawback originated from the aeration of the suspension with the shearing of the alum flocs due to the air bubbles in the system.

Although numerous studies were carried out considering the effect of the aeration on the treatment of the sewage sludge focusing on the biological oxidation [10-16], very few studies were reported for the aeration of the mineral wastewaters in the solid/liquid separation stage. To investigate the possible main effects and interactions of the aeration in this complicated physicochemical process, a detailed statistical analysis was carried out via irregular fractional design. Based on the obtained mathematical model, the response surface plots were drawn and the variation in the response variable throughout the studied limits of the parameters was comprehensively elucidated. As a result, the main and the interaction effects of the aeration parameter was determined as a function of $\mathrm{pH}$ and the metalcoagulant.

\section{Material and Methods}

The bentonite sample was collected from Eskişehir/Milahıççı region. The chemical composition of the sample was determined Spectro IQ X-Ray Flourescence (XRF) Spectrometer as follows: $62 \% \mathrm{SiO}_{2}$; $16 \% \mathrm{Al}_{2} \mathrm{O}_{3} ; 5 \% \mathrm{CaO} ; 4 \% \mathrm{Fe}_{2} \mathrm{O}_{3} ; 3 \% \mathrm{Na}_{2} \mathrm{O}$. Lost on ignition of the sample was also found as $6.8 \%$. The moisture of the original sample was determined as $8.2 \%$ in a lab-scale oven at $105^{\circ} \mathrm{C}$. The viscosity of the clay suspension was analyized at $600 \mathrm{rpm}$ via SOIF NDJ4 Viscosimeter and it was recorded as $62 \mathrm{cp}$. The particle size analysis was done with standard sieves. According to the weighing procedure of the retained material on the sive, $d_{100}$ was found as 34 micron. The physicochemical properties of the particles in the sample was determined by MALVERN ZETASIZER. The zetapotential of the particles were found as $-46 \mathrm{mV}$. This high negativity, which is an indication of the surface charge, explained the colloidal stability with the strong electrostatic repulsion between the colloids. The suspension (3\%$\mathrm{w} / \mathrm{w}$ ) was prepared by mixing a natural green-colored clay sample (bentonite) with distilled water (TDS $<2 \mathrm{ppm}$ ) at 1250rpm. After the complete dispersion of the colloidal particles, the suspension $\mathrm{pH}$ was adjusted according to the predetermined levels by using $\mathrm{NaOH}$ (MERCK with a purity greater than 97\%) and $\mathrm{HCl}$ (MERCK Hydrochloric acid fuming 37\% solutions). The aeration was done by using an air pump (RESUN $5 \mathrm{~W}$ ) with a capacity of $3.5 \mathrm{l} / \mathrm{min}$. An air stone was attached to the air pump and then dipped into the suspension to obtain fine bubbles. As coagulant, the aluminum sulphate in the hydrated form (MERCK with an $\mathrm{Al}_{2}\left(\mathrm{SO}_{4}\right)_{3}$-assay of 51-59\%) was preferred and the desired concentration of the coagulant was added to the suspension. The suspension was conditioned for 5 minutes for the adsorption of the coagulant. Following the coagulant addition, the suspension rested in a graduated cylinder for 20 minutes. At the end of the sedimentation period, the final volume of the agglomerated solid fraction was measured. 
To make systematic analysis, a design of experiment (DOE) technique by using Statgraphics Centurion software was implemented for the coagulation of the clay suspension. Irregular fraction design suggested the required experimental runs within the desired ranges of the parameters shown in Table 1 . These runs were experimentally carried out in the laboratory and the required data was practically collected and processed with the help of a statistical package. A statistical model was calculated and the statistical indicators of this model were determined to confirm the efficiency of the model. Based on the model, the response surface contours were drawn. The main effects and the interactions of the input parameters were explained by using the detailed response surfaces. Also, the variation in the response variable was clearly revealed. Finally, the process was statistically optimized by using the desirability concept.

Table 1. The range of the input parameters used in the experimental and statistical process.

\begin{tabular}{|c|c|c|}
\hline Statistical coding $\rightarrow$ & -1 : minimum value & 1 : maximum value \\
Parameters $\downarrow$ & 5 & 12 \\
$\mathrm{pH}$ & 0 & $3.51 / \mathrm{min}$ \\
Aeration & 0 & $1200 \mathrm{mg} / \mathrm{l}$ \\
\hline
\end{tabular}

\section{Results and Discussion}

According to the results of the initial statistical evaluation, the most effective mathematical equation for this experimental data set was determined as follows:

Sediment Vol. $=358.333+7.5 *$ Aeration $+19.375^{*} \mathrm{pH}-14.375^{*}$ Al-Coagulant $-10.0 *$ Aeration*pH

This simple mathematical expression sufficiently explained the variation in the studied cuboidal design region. In the given ANOVA table (Table 2), the p-value of each independent parameter was shown and their p-values were found less than or equal to 0.05 . This obtained information showed that all parameters applied in the coagulation experiments were statistically significant considering the variation in the response variable. The other significant statistical parameters, $R^{2}$ and adjusted- $\mathrm{R}^{2}$, were estimated satisfactorily high as $92.65 \%$ and $88.46 \%$, respectively. Minimum values of the standard error of estimate and the mean absolute errors were also obtained with this stated model. The Durbin-Watson statistics for the model was calculated as 2.30 with a p-value of 0.70 and it was confirmed that there was no autocorrelation in the dataset. Furthermore, the responses predicted by the model closely matched with the experimental observations as shown in Figure 1. Based on the ANOVA table and the statistical indicators, it was proved that the model was successfully constructed and it can be implemented in the interpretation and the optimization of the system.

Table 2. Analysis of Variance for Sediment Vol.

\begin{tabular}{|c|c|c|c|c|c|}
\hline Source & $\begin{array}{l}\text { Sum of } \\
\text { Squares }\end{array}$ & $D f$ & \begin{tabular}{|l|} 
Mean \\
Square
\end{tabular} & F-Ratio & P-Value \\
\hline B:Aeration & 675.0 & 1 & 675.0 & 5.37 & 0.05 \\
\hline C:pH & 4004.17 & 1 & 4004.17 & 31.88 & 0.00 \\
\hline D:Al- & 2204.17 & 1 & 2204.17 & 17.55 & 0.00 \\
\hline Coagulant & & & & & \\
\hline & 1200.0 & 1 & 1200.0 & 9.55 & 0.02 \\
\hline Total error & 879.167 & 7 & 125.595 & & \\
\hline Total (corr.) & 11966.7 & 11 & & & \\
\hline
\end{tabular}




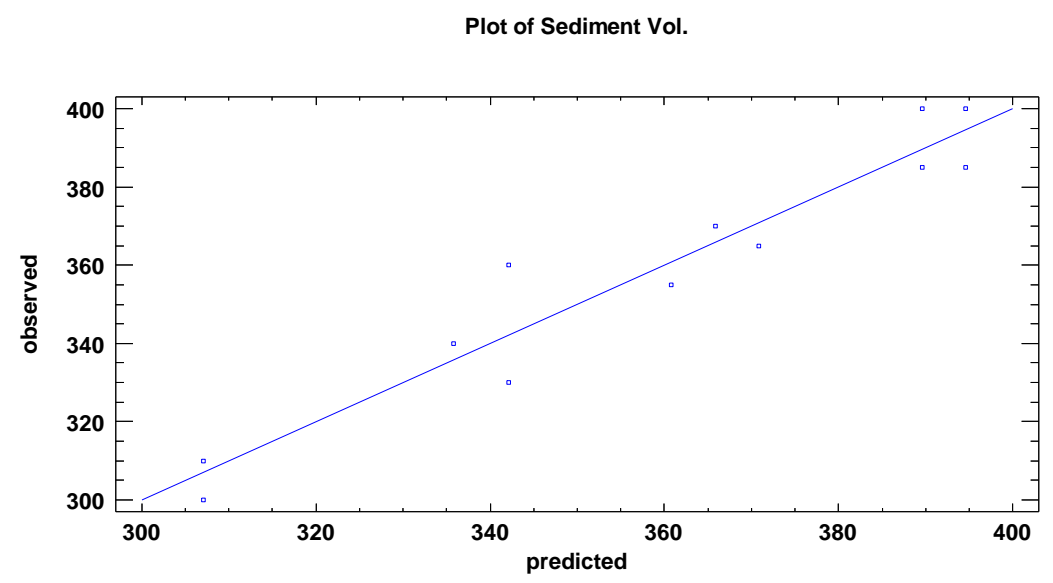

Figure 1. Observed vs. predicted values

The Pareto chart in Figure 2 identified the standardized effect of each parameter stated in the previous mathematical equation. According to the chart, the suspension $\mathrm{pH}$ had the greatest effect in this physicochemical process. The second important effect on the response variable was the amount of the added Al-Coagulant. In addition to these two input parameters, the statistical terms of B (Aeration) and $\mathrm{BC}$ (Aeration $\mathrm{x} \mathrm{pH}$ ) had a certain statistical effect on the dependent parameter. The main effect of these terms was summarized in Figure 3. The increase in the suspension $\mathrm{pH}$ generated higher sludge volumes after the coagulation. This drawback in the coagulation process was elucidated with hydrolyzed aluminum species. The hydrolysis of the aluminum maximized at the slightly acidic $\mathrm{pH}$ levels. During this hydrolysis process, the polymeric species of $\mathrm{Al}$ can be observed at $\mathrm{pH} 5$ for instance $\mathrm{Al}_{2}(\mathrm{OH})_{2}{ }^{4+}$, $\mathrm{Al}_{13} \mathrm{O}_{4}(\mathrm{OH})_{24}{ }^{7+}, \mathrm{Al}_{3}(\mathrm{OH})_{4}{ }^{5+}$ etc. These positively charged polymeric species can be firmly adsorbed on the negatively charged clay particles due to the strong electrostatic attraction between them. This kind of an interaction resulted in the effective sedimentation and lower sludge volumes. On the other hand, at the higher $\mathrm{pH}$ values, the concentration of the polymeric aluminum species decreased and the agglomeration process cannot be as efficient asto the previous case. For that reason, the relationship between the solution $\mathrm{pH}$ and the concentration of the polymeric aluminum species is of primary importance for the performance of the coagulation. As expected, Al-Coagulant significantly decreased the final volume of the sludge by enhancing the agglomeration process. When the concentration of the aluminum increased, the system contained more polymeric species in aquatic form. Such an increase results in the compression of the electrical double layer around the colloidal particles. This is another effective mechanism in the coagulation since the compression of the electrical double layer decreases the electrostatic repulsion between the particles. Once the electrostatic repulsion is eliminated in the system, the particles are easily destabilized and the sedimentation behavior improves as observed in this study (Figure 3). Nevertheless, the introduction of the air bubbles into the suspension resulted in the larger sediment volumes. Due to $\mathrm{SG}_{\text {air bubbles }}<\mathrm{SG}_{\text {water }}<\mathrm{SG}_{\text {particles, }}$ the bubbles introduced into the suspension tended to arise while the solid particles and their agglomerates tended to sediment in downward direction. During this movement, there was a collision between the solid and the gas phases. The collision generated a shear effect on the particle surface and prevented the compact agglomeration. The unfavorable shear effect generated by the bubbles deteriorated the coagulation process (Figure 3). The interaction plot (Figure 4) which belongs to the term BC (Aeration $\mathrm{x} \mathrm{pH}$ ) indicated the main interaction effect on the solid/liquid separation process. Especially at the acidic pH level of 5, the sediment volume presented a significant increasing trend due to the presence of the air bubbles in the system. The visual observation of the coagulation process indicated large/strong agglomerated structures in the absence of the air bubbles. However, the introduction of the air bubbles prevent the efficient particle-particle contact. Moreover, some bubbles were entrapped in the coagulated structure. As a result, as shown in Figure 4, the presence of the bubbles resulted in the larger and looser sediments and the process yielded higher sediment volumes. The combined effect of the aeration and $\mathrm{pH}$ was very limited at the higher $\mathrm{pH}$ since there was no firm and compact agglomerates formed under these alkaline 
conditions. The shearing effect of the arising bubbles cannot be observed for that reason. Depending on this primary output, it was ascertained that the interaction of the aeration and the solution $\mathrm{pH}$ during the coagulation can change the performance of the system and it should be taken into the consideration for the optimization of the experimental parameters.

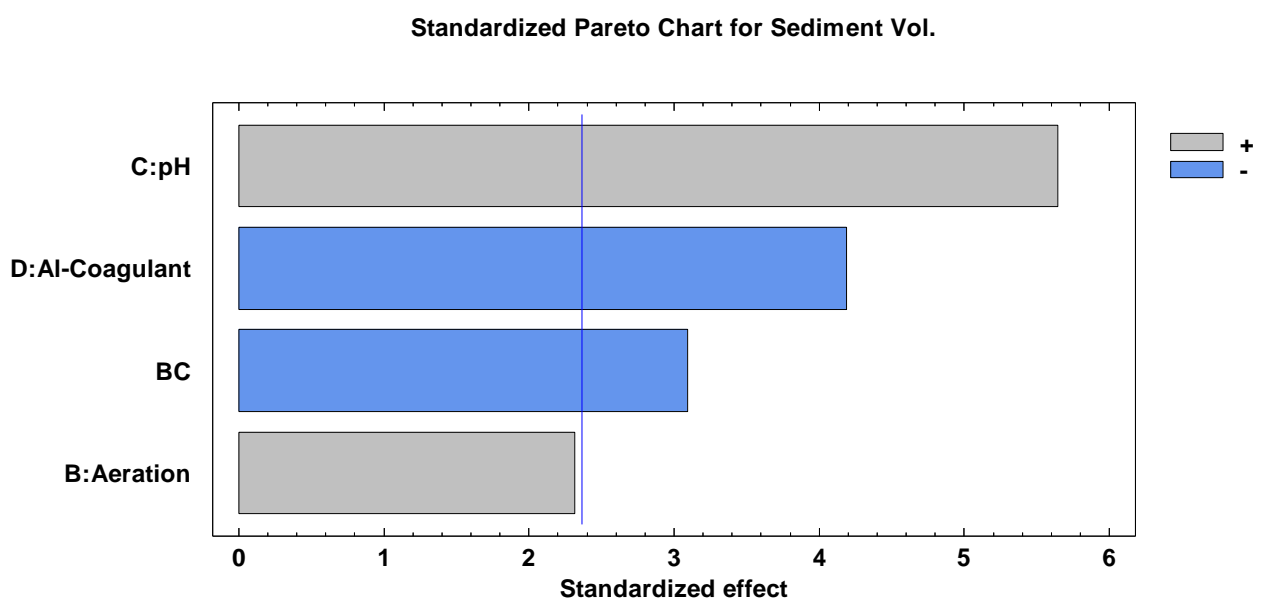

Figure 2. The standardized Pareto chart

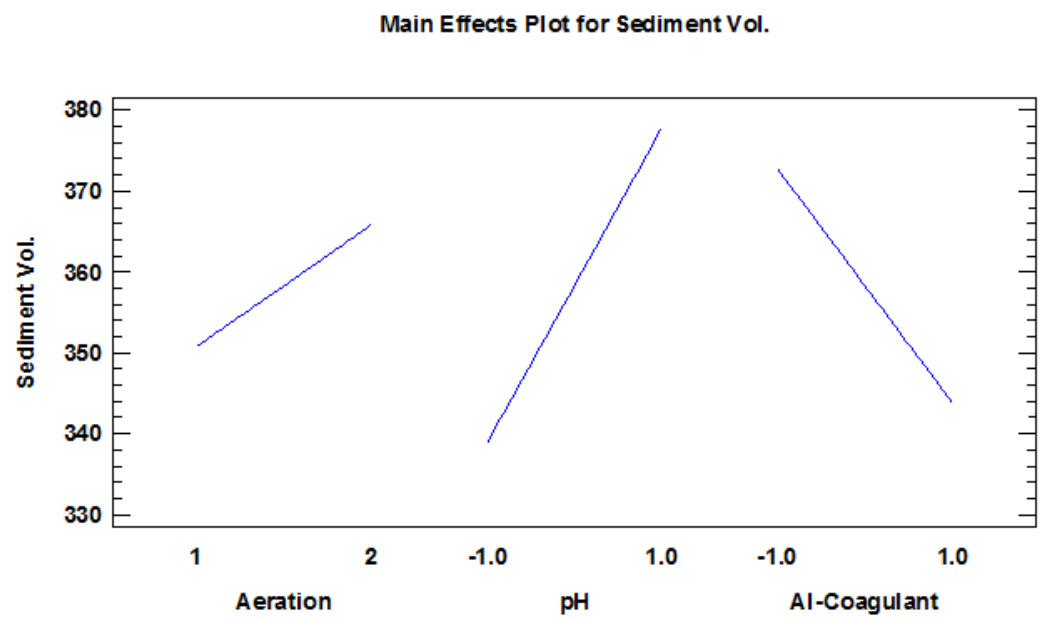

Figure 3. The main effects plot 
Interaction Plot for Sediment Vol.

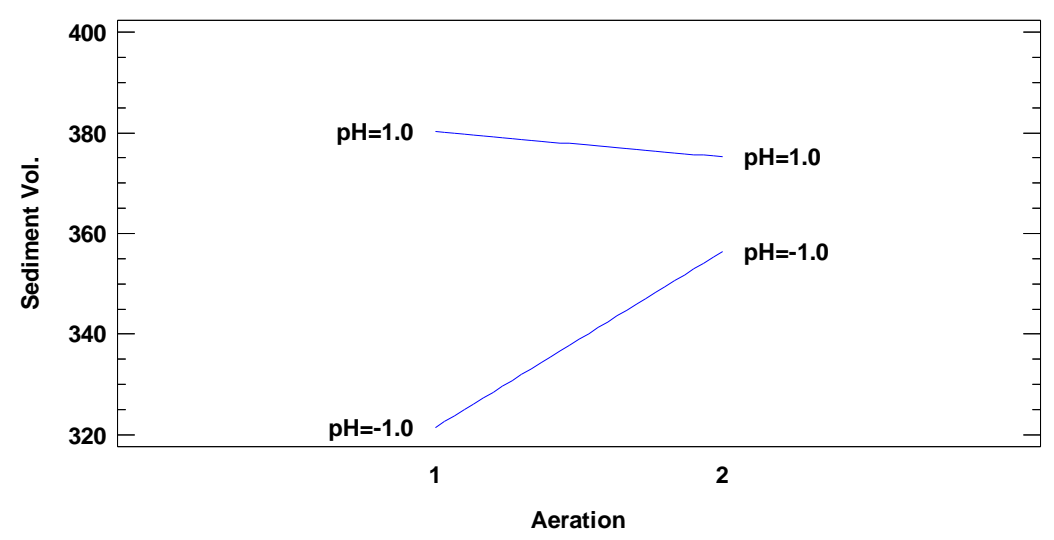

Figure 4. The interaction plot

The main and the interaction effect of the terms in the mathematical model was briefly explained, already. However, to understand the variation of the response variable as a function of the dependent parameters better, the response surface contours were drawn and presented in Figure 5, 6, and 7.

The highest sediment volumes were observed in the absence of the Al-Coagulant as shown in Figure 5. This explained that the suspension cannot be adequately dewatered without a proper treatment. In Figure 6 and 7, a varying amount of Al-Coagulant was added to the suspension and even such small doses of the coagulant diminished the volume of the sludge throughout the studied $\mathrm{pH}$ range. When the highest amount of the coagulant was used for the treatment of this colloidal suspension, the sediment volume significantly decreased down to $308 \mathrm{ml}$.

The solution $\mathrm{pH}$ was the most effective parameter as previously explained in the statistical analysis. The adjustment of the $\mathrm{pH}$ at any given parameter changed the performance of the system and the obtained sludge volume. For instance, at the alkaline $\mathrm{pH}$ values, the coagulating ability of the aluminum was lost and the dewatering process resulted in the higher sediment volumes greater than $360 \mathrm{ml}$. Nonetheless, at the acidic $\mathrm{pH}$ level of 5, the agglomerating capability of the aluminum maximized due to the predominant hydrolysis reactions. The hydrolyzed products of the aluminum improved the coagulation process and the larger agglomerates were formed. These larger structures resulted in the lesser mud volumes due to the enhanced compression of the sediment layer under the weight of these settled agglomerates $[17,18]$.

The effect of the aeration of the suspension was also determined considering the final volume of the coagulated mud. As presented in Figure 5, 6, and 7, the slurry aeration did not change the coagulation performance at the alkaline $\mathrm{pH}$ levels. This insensitivity of the process to the generated air bubbles in the alkaline suspension was explained with the insufficient coagulating ability of the aluminum. Since the hydrolysis reactions of the aqueous aluminum were not dominant in the alkaline environment, the agglomeration capability of the coagulant was very limited. As a result, very weak and very small agglomerated structures were formed at the higher $\mathrm{pH}$ values. The air bubbles could not penetrate into the finely agglomerated structures and, due to the limited interaction between the product of the coagulation and the generated air bubbles, no variation was observed for the final sediment volume. On the other hand, the stronger and larger agglomerates were formed at around $\mathrm{pH} 5$ since the hydrolysis reactions of the aluminum species took place at the acidic $\mathrm{pH}$ levels. During the formation of the larger agglomerates at $\mathrm{pH} 5$, the introduced air bubbles can be entrapped in this structure. This phenomenon led to the greater final sediment volumes after the coagulation was completed since the entrapped air occupied space inside the enlarged structure. As it can be summarized in Figure 5, 6, and 7 , the aeration during the coagulation at $\mathrm{pH} 5$ resulted in the greater sediment volumes. 


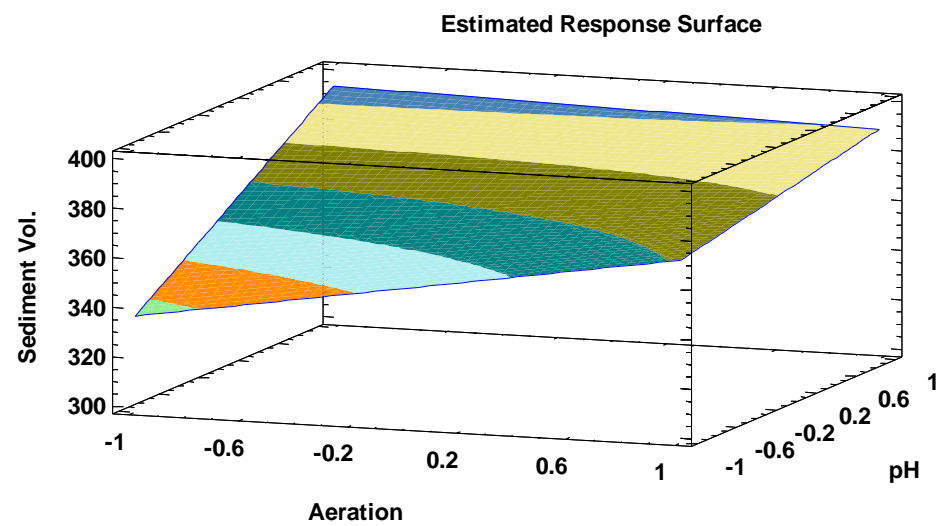

Sediment Vol. 300.0-310.0 $300.0-310.0$

$310.0-320.0$

$330.0-340.0$

$340.0-350.0$

$350.0-360.0$

$360.0-370.0$

$360.0-370.0$

370.0-380.0

$380.0-390.0$

$390.0-400.0$

Figure 5. Estimated response surface (Al-coagulant: 0mg/l)

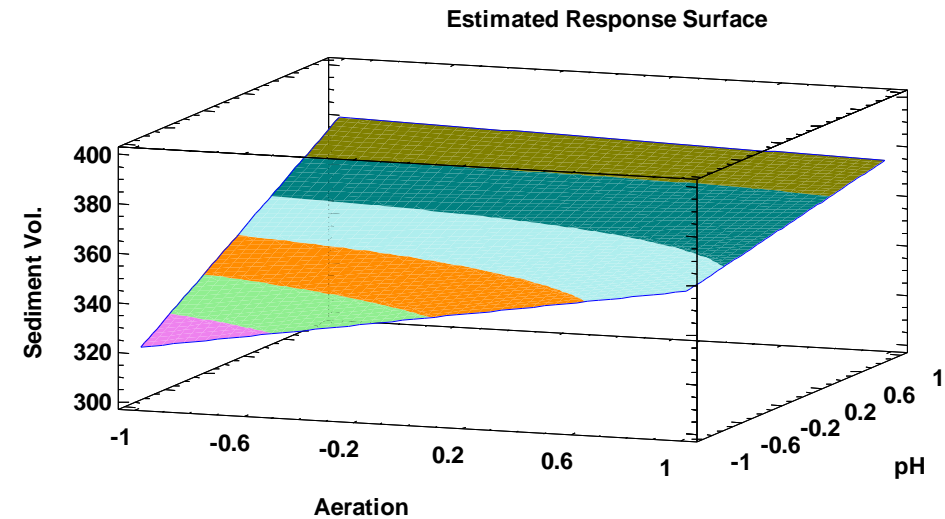

Sediment Vol. 300.0-310.

310.0-320.0

$320.0-330.0$

330.0-340.0

$340.0-350.0$

$350.0-360.0$

$360.0-370.0$

$370.0-380.0$

$380.0-390.0$

$390.0-400.0$

Aeration

Figure 6. Estimated response surface (Al-coagulant: 600 mg/l)

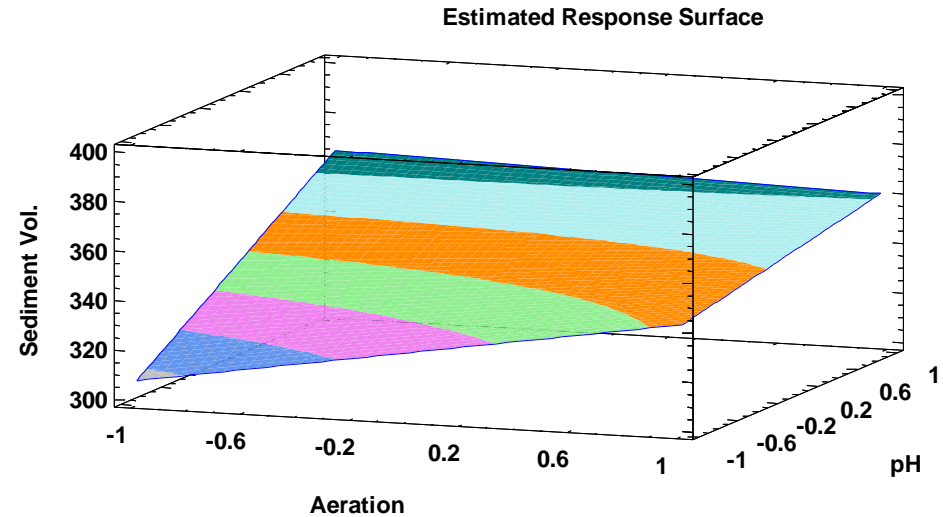

Sediment Vol.

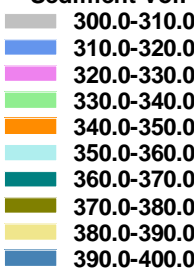

Figure 7. Estimated response surface (Al-coagulant: $1200 \mathrm{mg} / \mathrm{l}$ ) 
The optimization of the process showed that the least desirable conditions for the minimization of the sediment volume were $\mathrm{pH} 12$, no coagulant and, maximum aeration. However, to reach the most desirable outcome for the minimization of the sediment volume, the parameters should be arranged as follows: $\mathrm{pH} 5$, no aeration and, the maximum dose of the coagulant. The green region in Figure 8 represents the most desirable region whereas the grey-painted region represented the least desirable area. Nonetheless, it should be noted that the less dense agglomerates sometimes required for the easiness in the following filtration stages since the water molecules can more effectively pass through the lighter/non-compacted agglomerates and porous structure of the filter cloth. Based on such unusual technical requirements in a processing plant, the aeration of the slurry may be implemented to form lighter agglomerates regarding the efficiency in the subsequent dewatering stages.

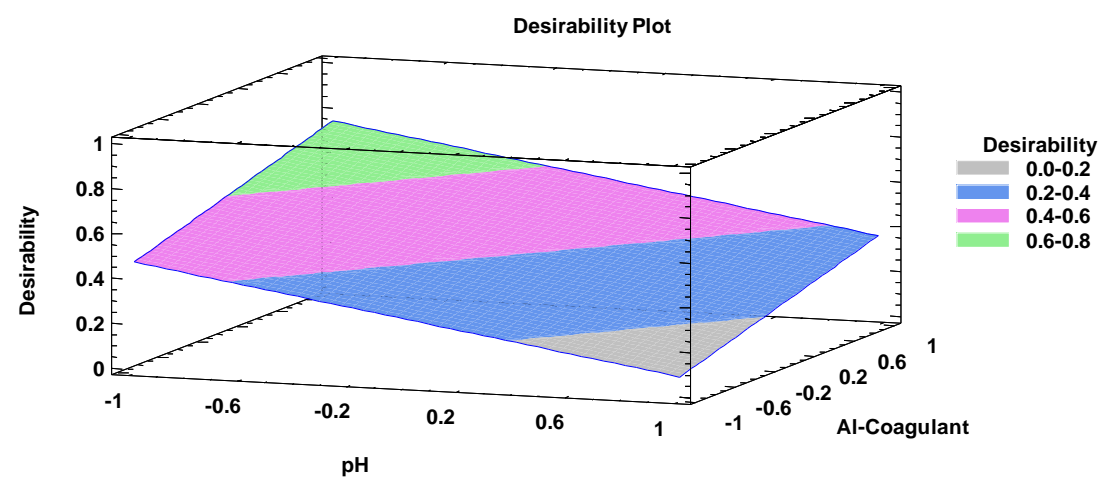

Figure 8. The desirability plot

\section{Conclusion}

The irregular factorial design analysis was implemented in this statistical study to determine the main effects and the interactions of each parameter used in the coagulation experiments. Following the completion of the experimental procedure for the required statistical design, the mathematical model for the process was formed by using the response surface methodology. $\mathrm{R}^{2}$ and adjusted- $\mathrm{R}^{2}$ values of the model were estimated as $92.65 \%$ and $88.46 \%$, respectively. The p-values of all parameters stated in the model were found smaller than $\leq 0.05$. The Pareto chart statistically showed that the most effective parameter in the process was the adjustment of the solution $\mathrm{pH}$. At the acidic $\mathrm{pH}$ levels, the response variable, the final sediment volume, was successfully minimized. The increase in the amount of the aluminum coagulant promoted the agglomeration process of the colloidal particles, especially at $\mathrm{pH} 5$. The combined effect of these two parameters was explained with the hydrolysis reactions of the aqueous aluminum, which was directly controlled by the solution $\mathrm{pH}$. Furthermore, the aeration of the suspension at the acidic $\mathrm{pH}$ levels resulted in the larger sediment volumes after the coagulation since the fine air bubbles entrapped in the agglomerated structure. Therefore, the optimization of the process concluded that the maximum amount of the Al-coagulant should be added at $\mathrm{pH} 5$ and no aeration should be applied for the minimization of the final sediment volume.

\section{Acknowledgement}

This work was supported by Mugla Sitki Kocman University, Scientific Research Projects Coordination Unit (Muğla, Turkey, MSKU-BAP 17/292). 


\section{References}

[1] Bian Z., Miao X., Lei S., Chen S.E., Wang W., Struthers S. 2012. The challenges of reusing mining and mineral-processing wastes. Science, 337 (6095): 702-703.

[2] Ahmad A.L., Sumathi S., Hameed B.H. 2006. Coagulation of residue oil and suspended solid in palm oil mill effluent by chitosan, alum and PAC. Chemical Engineering Journal, 118 (1-2): 99105.

[3] Dentel S.K. 1988. Application of the precipitation-charge neutralization model of coagulation. Environmental science \& technology, 22 (7): 825-832.

[4] Chang F.R.C., Sposito G. 1996. The electrical double layer of a disk-shaped clay mineral particle: Effects of electrolyte properties and surface charge density. Journal of Colloid and Interface Science, 178 (2): 555-564.

[5] Wang J.P., Chen Y.Z., Yuan S.J., Sheng G.P., Yu H.Q. 2009. Synthesis and characterization of a novel cationic chitosan-based flocculant with a high water-solubility for pulp mill wastewater treatment. Water research, 43 (20): 5267-5275.

[6] Ching H.W., Elimelech M., Hering J.G. 1994. Dynamics of coagulation of clay particles with aluminum sulfate. Journal of Environmental Engineering, 120 (1): 169-189.

[7] Choksuchart P., Héran M., Grasmick A. 2002. Ultra-filtration enhanced by coagulation in an immersed membrane system, Desalination, 145: 265-272.

[8] Konieczny K., Sąkol D., Bodzek M. 2006. Efficiency of the hybrid coagulation-ultrafiltration water treatment process with the use of immersed hollow-fiber membranes. Desalination, 198 (13): $102-110$.

[9] Knight T.E. 1982. Optimization of the coagulation process at the Carvins Cove Water Treatment Plant (Doctoral dissertation, Virginia Polytechnic Institute and State University).

[10] Lin L., Li R.H., Li X.Y. 2018. Recovery of organic resources from sewage sludge of Al-enhanced primary sedimentation by alkali pretreatment and acidogenic fermentation. Journal of Cleaner Production, 172: 3334-3341.

[11] Zhang J., Wu X., Qiu D., Mao J., Zhang H. 2017. Pilot-scale in situ treatment of landfill leachate using combined coagulation-flocculation, hydrolysis acidification, SBR and electro-Fenton oxidation. Environmental technology, 1-10.

[12] Jin X., Jin P., Hou R., Yang L., Wang X.C. 2017. Enhanced WWTP effluent organic matter removal in hybrid ozonation-coagulation (HOC) process catalyzed by Al-based coagulant. Journal of hazardous materials, 327: 216-224.

[13] Silva T.F., Vieira E., Lopes A.R., Nunes O.C., Fonseca A., Saraiva I., Vilar V.J. 2017. How the performance of a biological pre-oxidation step can affect a downstream photo-Fenton process on the remediation of mature landfill leachates: Assessment of kinetic parameters and characterization of the bacterial communities. Separation and Purification Technology, 175: 274286.

[14] Malik S.R., Awan B.A., Khan W.A., Islam Z.U., Mukhtar A., Shafiq U. 2017. Coagulation Flocculation Based Biological Treatment of Tannery Industry Wastewater using Potash Alum and Drewfloc. European Journal of Advances in Engineering and Technology, 4 (1): 71-75.

[15] Oloibiri V., Chys M., De Wandel S., Demeestere K., Van Hulle S.W. 2017. Removal of organic matter and ammonium from landfill leachate through different scenarios: Operational cost evaluation in a full-scale case study of a Flemish landfill. Journal of environmental management, 203: 774-781.

[16] Majumdar S., Sarkar S., Ghosh S., Bhattacharya P., Bandyopadhyay S., Saha A., Roy S.N. 2018. New Trends for Wastewater Treatment and Their Reuse Using Ceramic Membrane Technology: A Case Study. In Water Quality Management (pp. 339-348). Springer, Singapore.

[17] King R.P. 2002. Introduction to practical fluid flow. Elsevier.

[18] King R.P. 2012. Modeling and simulation of mineral processing systems. Elsevier. 